\title{
Distal element(s) is(are) required for position-independent expression of the goat $\alpha$-lactalbumin gene in transgenic mice. Potential relationship with the location of the cyclin T1 locus
}

\author{
Solange Soulier, Marie-Georges Stinnakre, \\ José Costa DA SILVA, Laurence LEPOURRY, \\ Xavier Mata, Nathalie Besnard, Jean-Luc Vilotte* \\ Unité de génétique biochimique et de cytogénétique, \\ Dêpartement de génétique animale, \\ Institut national de la recherche agronomique, \\ 78352 Jouy-en-Josas Cedex, France
}

(Received 17 May 2000; accepted 31 August 2000)

\begin{abstract}
We recently reported the site-independent and copy-number-related expression in mice of a goat $\alpha$-lactalbumin gene with $150 \mathrm{~kb}$ and $10 \mathrm{~kb}$ of $5^{\prime}$ - and $3^{\prime}$ flanking sequences, respectively. In the present study, we observed that the resection of the $5^{\prime}$-flanking region, leaving only $70 \mathrm{~kb}$, resulted in a site-dependent expression of this milk protein-encoding transgene. This suggests that important cis-regulatory elements are located within the distal-deleted sequence. Within this region, we localised the promoter of the cyclin $\mathrm{T} 1$ gene, an ubiquitously expressed gene. So far, no other gene has been located between these two loci. Since these two genes are differentially expressed, our data suggest the potential location of an insulator within the deleted region that allows the two genes to be independently regulated.
\end{abstract}

insulator / $\alpha$-lactalbumin / cyclin T1 / transgenesis / mice

Résumé - Un (ou plusieurs) élément(s) distal(aux) est(sont) nécessaire(s) pour une expression indépendante du site d'intégration du gène spécifiant l' $\alpha$-lactalbumine caprine dans des souris transgëniques. Possible corrélation avec la localisation du locus de la cycline T1. Nous avons récemment rapporté, dans des souris, l'expression indépendante du site d'intégration et proportionnelle au nombre de copies d'un transgène de $160 \mathrm{~kb}$. Cet ADN comportait l'unité de transcription du gène de I' $\alpha$-lactalbumine caprine, une protéine majeure du lait, ainsi que $150 \mathrm{~kb}$ de séquence amont et $10 \mathrm{~kb}$ de séquence avale. Dans la présente étude, nous observons que l'expression de ce gène devient dépendante du site d'intégration s'il ne subsiste que $70 \mathrm{~kb}$ de séquence amont. Ce résultat indique la présence d'éléments

\footnotetext{
* Correspondence and reprints

E-mail:vilotte@biotec.jouy.inra.fr
} 
cis-régulateurs importants dans la région distale éliminée. Dans cette région, nous avons identifié le promoteur du gène de la cycline $T 1$, gène qui est exprimé dans tous les tissus. Á ce jour, aucun autre gène n'a été localisé entre ces deux loci, suggérant la présence d'une séquence isolatrice dans la région distale absente du transgène utilisé ici. Une telle séquence contribuerait à la régulation indépendante in vivo de ces deux gènes.

séquence isolatrice / $\alpha$-lactalbumine / cycline T1 / transgénèse / souris

\section{INTRODUCTION}

Random-integration of transgenes into the genome, obtained by microinjection, often results in unpredictable regulation of introduced genes. This so-called "position-effect" is attributed to the influence of the chromatin surrounding the transgene on its expression. It means that several transgenic lines have to be created for one construct in order to obtain animals that express the gene of interest in the appropriate manner, increasing the cost of such experiments.

Position-independent expression of several genes in transgenic animals has been reported and was found to be associated with the occurrence within the injected DNA of dominant cis-regulatory elements such as insulators or locuscontrol regions $[1,8]$. Such dominant cis-regulatory elements have yet to be identified in a milk protein locus. However, position-independent expression of the human and goat $\alpha$-lactalbumin $(\alpha$ lac) genes in transgenic rats and mice, respectively, was recently achieved using long genomic fragments isolated from YAC or BAC libraries $[5,15]$. In the present study, we refined the location of these dominant cis-regulatory elements within a goat $\alpha$ lac BAC clone and analysed its relationship with the occurrence, also within this same BAC DNA, of at least part of the cyclin $\mathrm{T} 1$ locus.

\section{MATERIALS AND METHODS}

\subsection{Resection of the $\alpha$ lac Bac41 genomic insert}

The $160 \mathrm{~kb}$ insert of Bac41, comprising the transcription unit of the $\alpha$ lac gene with $150 \mathrm{~kb}$ and $10 \mathrm{~kb}$ of $5^{\prime}$ and $3^{\prime}$ flanking sequences, respectively [15], was digested by $S a l I$. The two co-migrating $80 \mathrm{~kb}$ restriction fragments were gel-purified and ligated into the XhoI site of pAB3.6 (a kind gift from Dr A. Billault, Molecular Engines Laboratories, France). This vector is derived from pBeloBAC11 and has a unique XhoI site located within the poly-linker region. The recombinant vector carrying the $80 \mathrm{~kb}$ insert encompassing the $\alpha$ lac transcription unit was identified by screening the colonies with a bovine fulllength $\alpha$ lac cDNA probe, as previously described [16]. Restriction mapping analysis, end-sequencing and isolation for micro-injection of the $\mathrm{BAC}$ insert from the identified Bac6 clone were performed as previously described [15]. 


\subsection{Creation of transgenic mice}

The purified Bac6 insert was micro-injected at a concentration of $1 \mathrm{ng} \cdot \mu \mathrm{L}^{-1}$ into the pronuclei of C57Bl6 X CBA fertilised oocytes. Transgenic mice were identified by Southern blotting of PstI-digested, tail-purified genomic DNA. The blot was probed with a bovine full-length $\alpha$ lac cDNA probe. Estimation of the copy number of integrated transgenes in each line was performed by comparative analysis of the hybridisation signals obtained in Southern blots probed with a mixture of bovine and murine full-length $\alpha$ lac cDNA probes, as previously described [15].

\subsection{Expression analysis of the goat $\alpha$ lac insert}

Northern-blot analyses were performed using $20 \mu \mathrm{g}$ of total RNA per sample that were size-fractionated in formaldehyde/agarose gels, as described [17]. Western blots were performed on $14 \%$ SDS/PAGE gels transferred onto a nitrocellulose membrane using a rabbit anti-bovine $\alpha$ lac antiserum [17]. The goat $\alpha$ lac content of the milk was estimated using purified bovine $\alpha$ lac samples of known concentrations and by scanning the blots using a Pharmacia LKB imagemaster DTS scanning system, according to the manufacturer's instructions.

\section{RESULTS}

\subsection{Resection of the Bac41 insert and generation of transgenic mice}

Following the digestion of the Bac41 genomic insert by SalI and the subcloning of the restriction fragments into the XhoI site of pAB3.6, a Bac6 clone was isolated. The $80 \mathrm{~kb}$ insert of this clone encompassed the transcription unit of the goat $\alpha \mathrm{lac}$ gene alongside about $70 \mathrm{~kb}$ and $10 \mathrm{~kb}$ of $5^{\prime}$ and $3^{\prime}$ flanking regions, respectively. The purified insert was micro-injected into the pronuclei of C57Bl6 X CBA fertilised oocytes. Six transgenic founder mice were identified by Southern blotting analysis of their tail-purified genomic DNA. All founders but one sterile male transmitted the transgene to their progeny and G1 animals were studied for transgene expression. The numbers of integrated copies were estimated by Southern analysis of G1 mice genomic DNA using the murine $\alpha$ lac hybridisation signal as an internal standard [15] and are reported in Table I. PCR-analyses of the integrated transgenes revealed that the edges of the BAC insert were present in animals of each of the five lines analysed (data not shown). Incidentally, sequencing analysis of the BAC edges revealed no significant, homology with known sequences at its $3^{\prime}$-end, as already observed for BAC41 [15], whereas at its $5^{\prime}$-end more than $80 \%$ homology was detected over DNA segments of around $100 \mathrm{bp}$ in length with both a human chromosome 7 PAC clone (GenBank: ac005518) and an ovine microsatellite (GenBank: af259710). 
Table I. Quantification of Southern and Western analyses.

\begin{tabular}{ccc}
\hline Line & $\begin{array}{c}\text { Estimated transgene } \\
\text { copy number }\end{array}$ & $\begin{array}{l}\text { Estimated goat } \alpha \mathrm{lac} \\
\text { milk content }\left(\mathrm{mg} \cdot \mathrm{mL}^{-1}\right)^{*}\end{array}$ \\
\hline 09 & 2 & 0.25 \\
23 & 6 & 3 \\
27 & 1 & 0.6 \\
28 & 4 & 0.01 \\
31 & 2 & 0.35 \\
\hline
\end{tabular}

* Mean values from two independent measurements.

\subsection{Transgene expression analysis}

Goat $\alpha$ lac transcripts were detected in the lactating mammary gland of mice from the five analysed transgenic lines (Fig. 1 and data not shown). The transgene in four out of the five lines analysed was specifically expressed in the mammary gland since no ectopic expression of the goat $\alpha$ lac mRNA was detected in the liver, brain, thymus, kidney and salivary gland or male testis. However, in animals from line 27, a low level of expression of the transgene was observed in the brain (data not shown).

Western blot analysis of milk from at least two 7-day lactating mice per line revealed the presence of the goat recombinant protein (Fig. 2 and Tab. I). The estimated amount of goat $\alpha$ lac reflected the amount of its mRNA in the mammary gland (data not shown). No correlation was observed between the estimated number of integrated copies of Bac6 and the amount of recombinant goat protein in the milk (Tab. I).

Developmental regulation of the transgene was analysed in the gestating mammary gland of mice from lines 23 and 27 (Fig. 1). In animals from line 23, the regulation of the transgene was found to be similar to that of the endogenous murine alac gene, whereas it was different in mice from line 27 (Fig. 1).

\subsection{Location of the goat cyclin $\mathrm{T} 1$ locus}

Two exons from the goat cyclin $\mathrm{T} 1$-encoding gene were identified within Bac41 DNA and its partial cDNA, encompassing the entire coding region and the $5^{\prime}$-UTR, was subsequently isolated (Mata et al., unpublished data). When a $200 \mathrm{bp} 5^{\prime}$-sub-fragment of this cDNA, corresponding to part of the first exon of the gene, was used to probe DNA from Bac41 and Bac6, it was observed that this region of the gene was present within the Bac41 DNA but absent from Bac6 (Fig. 3). Partial sequencing analysis of this hybridizing fragment revealed that it includes $350 \mathrm{bp}$ of the promoter of the gene which shares $71 \%$ homology with that of the homologous human locus (GenBank af255307, Mata et al., unpublished data). Thus the promoter of the goat cyclin T1-encoding gene is part of the distal region of Bac41 that has been deleted in Bac6. 


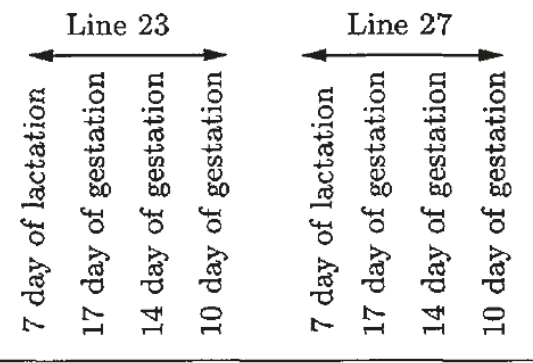

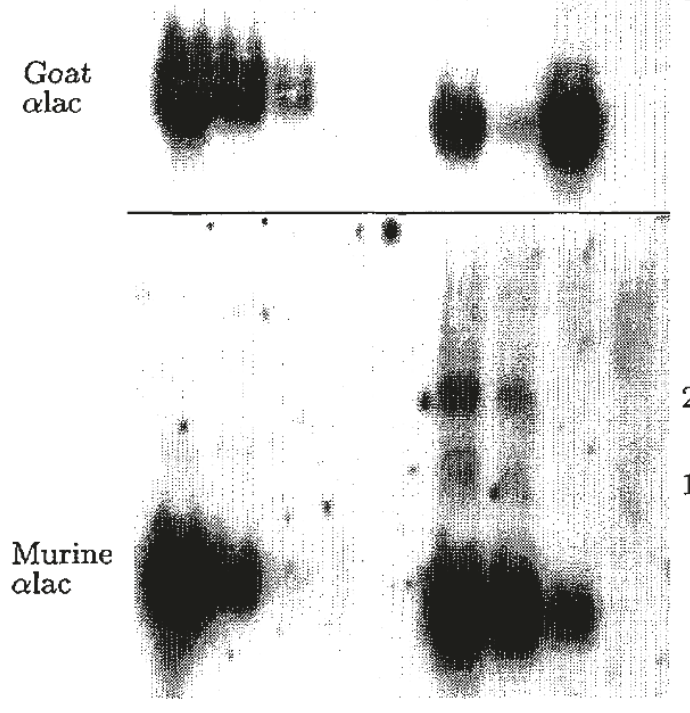

Figure 1. Developmental regulation in the mammary gland of the goat $\alpha$ lac transgene. Northern blots were performed using $20 \mu \mathrm{g}$ of total mammary RNA from animals from lines 23 and 27 . The origins of the samples are indicated at the top. $28 \mathrm{~S}$ The membrane was hybridised successively with a bovine alac cDNA probe, stripped and re-hybridised with a murine alac cDNA probe, as indicated on the left margin. Positions of the $18 \mathrm{~S}$ and $28 \mathrm{~S}$ RNAs are indicated on the right margin.

\section{DISCUSSION}

\subsection{Resection of the $5^{\prime}$ flanking region of Bac41 results in a site-dependent expression of the goat $\alpha$ lac gene in transgenic mice}

We have recently reported that the micro-injection of the $160 \mathrm{~kb}$ Bac41 insert resulted in a site-independent, copy-number-related, developmentallyregulated and tissue-specific expression of the goat clac gene [15]. To further define the location of the dominant cis-regulatory element, we have shortened the $5^{\prime}$ flanking region of this gene from $150 \mathrm{~kb}$ to $70 \mathrm{~kb}$. The insert of this 


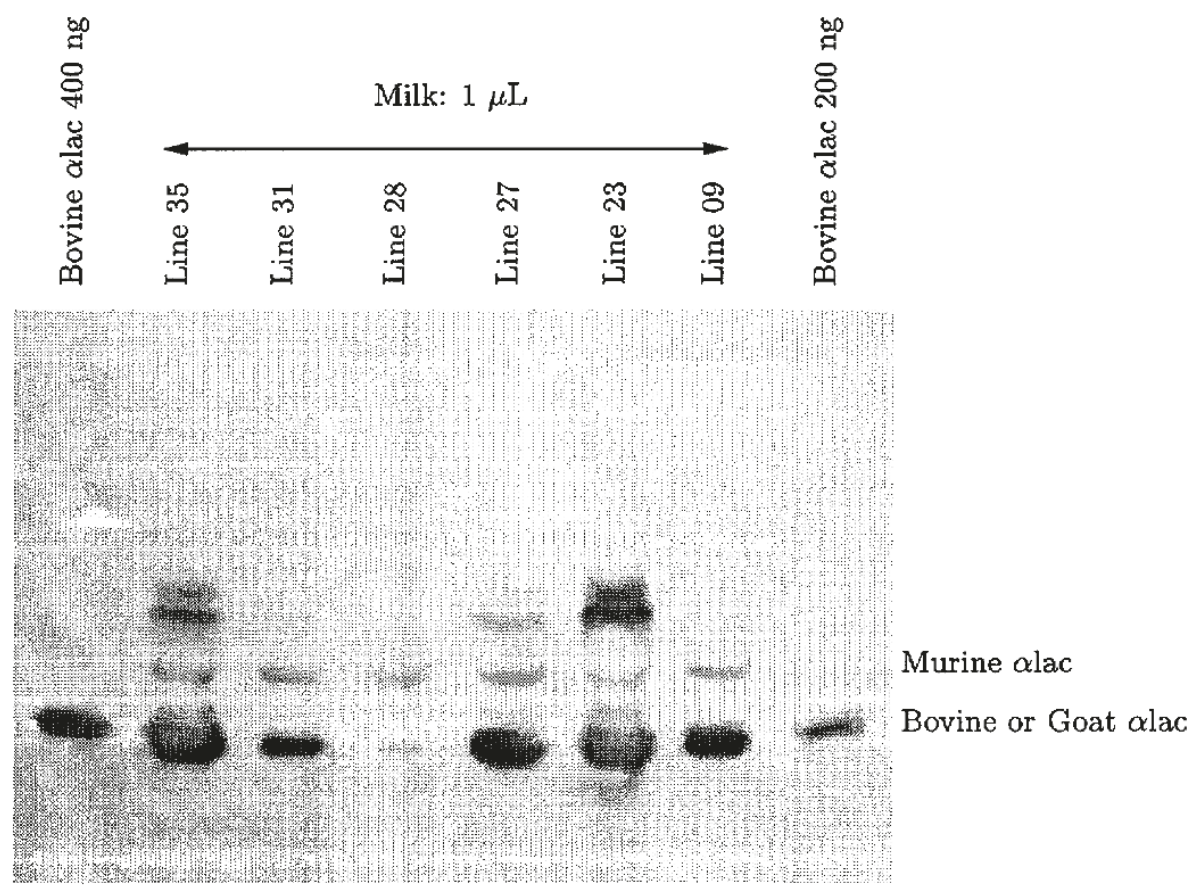

Figure 2. Western blot analysis of milk. Origins and amounts of samples are indicated at the top. Positions of murine and of the major form of goat or bovine alac are indicated on the right margin. Minor potentially glycosylated forms of goat $\alpha$ lac can be seen in some milk samples. Line 35 is a transgenic line carrying the Bac41 transgene that has been previously described [15].

new BAC clone, Bac6, encompassed 70 and $10 \mathrm{~kb}$ of $5^{\prime}$ and $3^{\prime}$ flanking regions, respectively. Expression analysis of this gene in transgenic mice revealed that it suffered from the so-called position effect. Indeed the $\alpha$ lac expression level became independent from the number of copies of the transgene integrated (Tab. I) and ectopic expression was observed in one of the five transgenic lines analysed. The developmental expression pattern of the goat $\alpha$ lac gene was also affected in the gestating mammary gland of mice from line 27 (Fig. 1). In this line, the developmental profile of the goat olac gene showed unexpected levels of expression at day 14 and 17 of gestation, whereas that of the endogenous $\alpha$ lac gene was normal. This unexpected pattern of goat $\alpha$ lac gene expression might result from a mosaic activity of the promoter in the mammary gland. Such heterogeneous gene expression in the mammary gland has already been reported for transgenes using $\beta$-lactoglobulin [4], MMTV or WAP [9, 10] regulatory elements. Overall, these data demonstrated that important cis-regulatory elements that confer to the goat $\alpha$ lac gene a site-independent expression in transgenic mice are located far upstream $5^{\prime}$ of its transcription unit, within the $80 \mathrm{~kb}$ DNA fragment that has been deleted from Bac4l to create Bac6. 


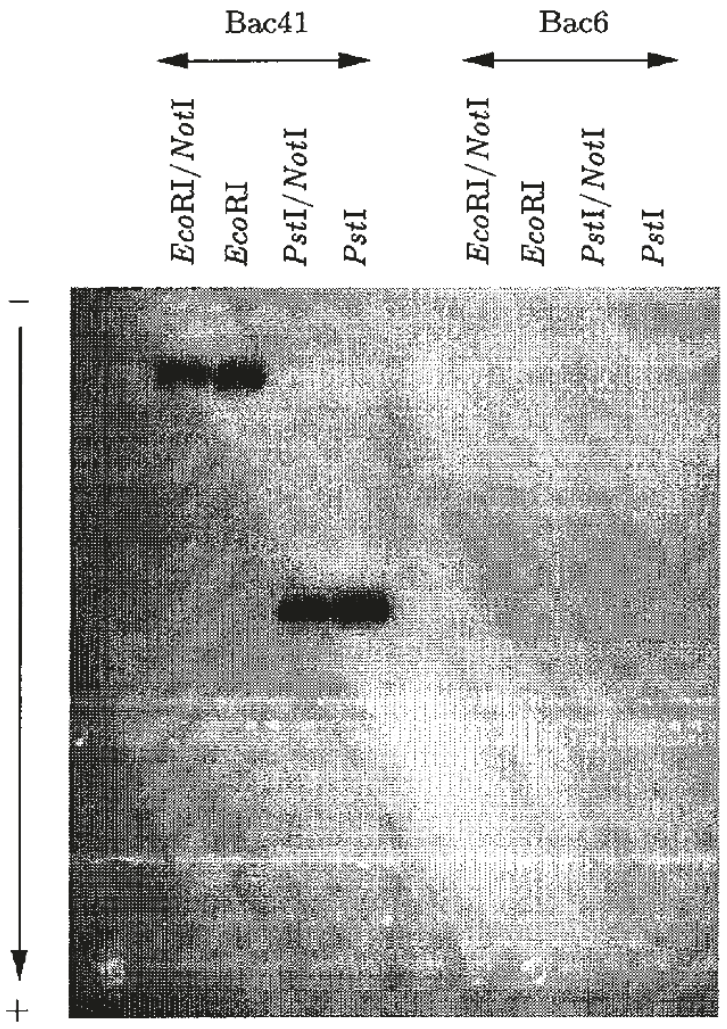

Figure 3. Southern blotting analysis of Bac41 and Bac6 DNAs. Southern blotting experiments were performed using equal amounts of digested BAC DNAs. Origin of the DNA and restriction enzymes used are indicated at the top. The mem. brane was hybridised with a $200 \mathrm{bp}$ probe derived from the first exon of the cyclin $\mathrm{T} 1$ gene.

Analysis of the expression of the human $\alpha$ lac gene in transgenic rats has recently permitted to locate important cis-regulatory elements for its siteindependent expression in both the $50 \mathrm{~kb}$ upstream and downstream regions of its transcription unit [6]. Thus, the location of such cis-regulatory elements with regards to the transcription initiation site appears to be different between the human and the goat homologous loci. Such apparent discrepancies are often observed between homologous genes and can often be attributed to the insertion/deletion of DNA fragments like repetitive DNA elements ([19] for example).

\subsection{Potential relationship with the location of the goat cyclin $\mathbf{T} \mathbf{1}$ locus}

A second gene locus has been identified within the Bac41 genomic insert. It corresponds to the gene encoding cyclin $\mathrm{T} 1$. This protein acts as a cofactor for human immunodeficiency virus type 1 (HIV1) nuclear transcriptional activator or Tat protein $[2,18]$. Both $\alpha \mathrm{lac}$ and cyclin T1 loci have been assigned to human chromosome 12 (region 12q12-12q13). So far, no other gene has been identified within these two loci (http://www.gdb.org/hugo/chr12). By Southern blotting analyses, we located the goat cyclin $\mathrm{T} 1$ promoter within the $80 \mathrm{~kb}$ genomic 


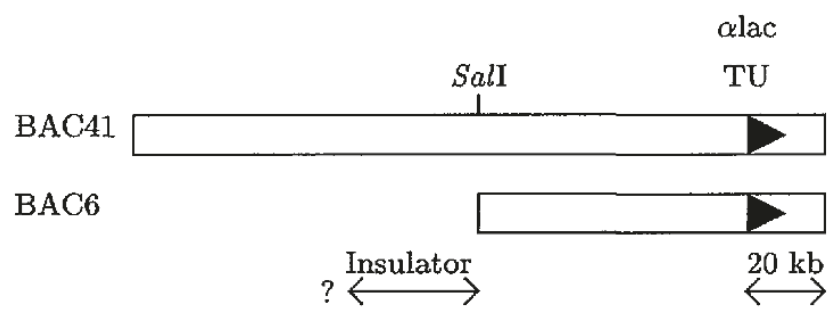

Figure 4. Schematic representation of BAC41 and Bac6. alac TU: location of the olac transcription unit. Length of the transcription unit is not at scale, ?: putative location of the cyclin $\mathrm{T} 1$ promoter which has yet to be precisely mapped. The large arrow indicates the region into which the insulator would be located.

fragment deleted from the Bac41 to generate the Bac6. Whereas the olac gene expression is restricted to the mammary gland at precise physiological stages [11], the cyclin T1 gene is expressed widely in adult tissues [18]. These two genes are thus independently regulated although they are physically closely linked.

One attractive hypothesis would be that these two genes are actually located within two different domains of gene expression $[1,7,8]$. Boundaries in chromatin that define such domains, are often associated with the occurrence of insulator elements, of which one of the most extensively studied is the chicken $\beta$-globin insulator [3]. Interestingly, this chicken $\beta$-globin insulator was recently shown to separate the globin locus from the independently-regulated folate receptor gene [13], a situation resembling that describe here. The occurrence of an insulator element able to protect the $\alpha$ lac gene against position effects within the deleted $80 \mathrm{~kb}$ DNA fragment of Bac41 could explain our present data (Fig. 4). This element could be located between the cyclin T1 promoter and the restriction $\mathrm{SalI}$ site used to generate the Bac6 clone. It would be interesting to comparatively physically map the cyclin $\mathrm{T} 1$ and the $\alpha$ lac promoters in both human and goat species and to search for sequence homologies between the two intergenic regions. Such analyses could speed up the identification of dominant cis-regulatory elements. Incorporation of such elements into existing mammary expression vectors would be of great economical value not only for biopharmaceutical productions that use the mammary gland as a bioreactor [14] but also for other nutritional, physicochemical and technological modifications of milk [12].

\section{ACKNOWLEDGEMENTS}

We are most grateful to Dr A. Billault (Molecular Engines Laboratories, France) for the kind gift of the pAB3.6 vector. This work was partially supported by an AIP-transgénèse from the Institut national de la recherche agronomique. 


\section{REFERENCES}

[1] Bell A.C., Felsenfeld G., Stopped at the border: boundaries and insulators, Curr. Opin. Genet. Dev. 9 (1999) 191-198.

[2] Bieniasz P.D., Grdina T.A., Bogerd H.P., Cullen B.R., Recruitment of a protein complex containing Tat and cyclin T1 to TAR governs the species specificity of HIV-1 Tat, EMBO J. 17 (1998) 7056-7065.

[3] Chung J.H., Bell A.C., Felsenfeld G., Characterization of the chicken $\beta$-globin insulator, Proc. Natl. Acad. Sci. USA 94 (1997) 575-580.

[4] Faerman A., Barash I., Puzis R., Nathan M., Hurwitz D.R., Shani M., Dramatic heterogeneity of transgene expression in the mammary gland of lactating mice: a model system to study the synthetic activity of mammary epithelial cells, J. Histochem. Cytochem. 43 (1995) 461-470.

[5] Fujiwara Y., Miwa M., Takahashi R., Hirabayashi M., Suzuki T., Ueda M., Position-independent and high-level expression of human $\alpha$-lactalbumin in the milk of transgenic rats carrying a 210 kb YAC DNA, Mol. Reprod. Dev. 47 (1997) 157-163.

[6] Fujiwara Y., Takahashi R., Miwa M., Kameda M., Kodaira K., Hirabayashi M., Suzuki T., Ueda M., Analysis of control elements for position independent expression of human $\alpha$-lactalbumin YAC, Mol. Reprod. Dev. 54 (1999) 17-23.

[7] Gerasimova T.I., Corces V.G., Boundary and insulator elements in chromosomes, Curr. Opin. Genet. Dev. 6 (1996) 185-192.

[8] Geyer P.K., The role of insulator elements in defining domains of gene expression, Curr. Opin. Genet. Dev. 7 (1997) 242-248.

[9] Hennighausen L., Wall R.J., Tillmann U., Li M., Furth P.A., Conditional gene expression in secretory tissues and skin of transgenic mice using the MMTV-LTR and the tetracycline responsive system, J. Cell. Biochem. 59 (1995) 463-472.

[10] Li B., Greenberg N., Stephens L.C., Meyn R., Medina D., Rosen J.M., Preferential overexpression of a 172 Arg-Leu mutant p53 in the mammary gland of transgenic mice results in altered lobulo-alveolar development, Cell Growth Differ. 5 (1994) 711-721.

[11] Mercier J.C., Vilotte J.L., Structure and function of milk protein genes, J. Dairy Sci. 76 (1993) 3079-3098.

[12] Mercier J.C., Vilotte J.L., The modification of milk protein composition through transgenesis: progress and problems, in: Houdebine L.M. (Ed.), Transgenic animals-generation and use, Harwood Academic Publishers, Switzerland, 1997, pp. 473-482.

[13] Prioleau M.N., Nony P., Simpson M., Felsenfeld G., An insulator element and condensed chromatin region separate the chicken $\beta$-globin locus from an independently regulated erythroid-specific folate receptor gene, EMBO J. 18 (1999) 4035-4048.

[14] Rudolph N.S., Biopharmaceutical production in transgenic livestock, TIBTECH 17 (1999) 367-374.

[15] Stinnakre M.G., Soulier S., Schibler L., Lepourry L., Mercier J.C., Vilotte J.L., Position-independent and copy-number-related expression of a goat bacterial artificial chromosome $\alpha$-lactalbumin gene in transgenic mice, Biochem. J. 339 (1999) 33-36.

[16] Vilotte J.L., Soulier S., Mercier J.C., Gaye P., Hue-Delahaie D., Furet J.P., Complete nucleotide sequence of bovine $\alpha$-lactalbumin gene: comparison with its rat counterpart, Biochimie 69 (1987) 609-620. 
[17] Vilotte J.L., Soulier S., Stinnakre M.G., Massoud M., Mercier J.C., Efficient and tissue-specific expression of bovine $\alpha$-lactalbumin in transgenic mice, Eur. J. Biochem. 186 (1989) 43-48.

[18] Wei P., Garber M.E., Fang S.M., Fischer W.H., Jones K.A., A novel CDK9associated c-type cyclin interacts directly with HIV-1 Tat and mediates its high affinity, loop-specific binding to TAR RNA, Cell 92 (1998) 451-462.

[19] Winklehner-Jennewein P., Geymayer S., Lechner J., Welte T., Hansson L., Geley S., Doppler W., A distal enhancer region in the human $\beta$-casein gene mediates the response to prolactin and glucocorticoid hormones, Gene 217 (1998) 127-139.

To access this journal on line: www.edpsciences.org 